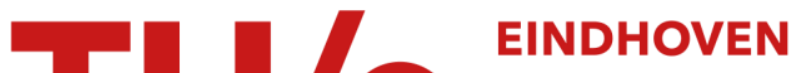 UNIVERSITY OF TECHNOLOGY
}

\section{Economics of in-building optical fiber networks}

\section{Citation for published version (APA):}

Koonen, A. M. J., Boom, van den, H. P. A., Tangdiongga, E., Ortega Martinez, E., \& Pizzinat, A. (2011). Economics of in-building optical fiber networks. In O. Ziemann (Ed.), POF-Plus Handbook : handbook of the European POF-PLUS Project 2008-2011 (pp. 90-95). POF plus project.

\section{Document status and date:}

Published: 01/01/2011

\section{Document Version:}

Publisher's PDF, also known as Version of Record (includes final page, issue and volume numbers)

\section{Please check the document version of this publication:}

- A submitted manuscript is the version of the article upon submission and before peer-review. There can be important differences between the submitted version and the official published version of record. People interested in the research are advised to contact the author for the final version of the publication, or visit the $\mathrm{DOI}$ to the publisher's website.

- The final author version and the galley proof are versions of the publication after peer review.

- The final published version features the final layout of the paper including the volume, issue and page numbers.

Link to publication

\section{General rights}

Copyright and moral rights for the publications made accessible in the public portal are retained by the authors and/or other copyright owners and it is a condition of accessing publications that users recognise and abide by the legal requirements associated with these rights.

- Users may download and print one copy of any publication from the public portal for the purpose of private study or research.

- You may not further distribute the material or use it for any profit-making activity or commercial gain

- You may freely distribute the URL identifying the publication in the public portal.

If the publication is distributed under the terms of Article $25 \mathrm{fa}$ of the Dutch Copyright Act, indicated by the "Taverne" license above, please follow below link for the End User Agreement:

www.tue.nl/taverne

Take down policy

If you believe that this document breaches copyright please contact us at:

openaccess@tue.nl

providing details and we will investigate your claim. 


\section{Economics of In-Building Optical Fiber Networks}

Ton Koonen, Henrie van den Boom, Eduward Tangdiongga, COBRA-TU Eindhoven, The Netherlands

Eduardo Ortego Martinez, Telefonica I+D, Valladolid, Spain Anna Pizzinat, Philippe Guignard, France Telecom R\&D, Lannion, France

Abstract: Optical fiber in-building networks integrating wirebound and wireless services can outperform Cat-5E networks regarding versatility and costs, in particular when sharing ducts with electricity wiring. POF-based point-topoint topologies are optimum for small buildings, and POF-based opaque bus topologies for larger buildings.

\section{In-building networks}

Regarding technical performance, an optical fiber in-building network is optimally suited to extend fiber-to-the-home's large capacity and service flexibility into the home [1], [2]. To gain wide acceptance, however, also the economical aspects are of major importance. Silica single-mode fiber (SMF) offers the ultimate bandwidth performance, but its tiny core requires precision tools and skilled personnel for installation. Silica multimode fiber (MMF) is easier to handle and less vulnerable due to its larger core, but still needs delicate tools for connectorization. Large-core (1 $\mathrm{mm}$ diameter) plastic optical fiber (POF), due to its large core and ductility, is very easy to handle, making it even suitable for do-it-yourself installation. With respect to SMF and MMF, the POF's higher losses and lower bandwidth restrict its use to shorter lengths. Advanced signal modulation techniques allow to overcome the bandwidth restrictions and thus to realize multi-Gbit/s data links as well as microwave radio-over-fiber systems, albeit over short link lengths (up to about 100 meters), which are however well-suited for in-building networks. In the in-building domain, Cat-5E solutions with their enormous market volume have reached low cost levels. Next to the technical performance superiority, also the economics of fiber-based solutions therefore have to be assessed. The installation costs (CapEx, capital expenditure) and operational 
costs (OpEx, operational expenditure) of various fiber network solutions will be investigated, and compared with those of Cat-5E solutions.

\section{Network topologies}

A number of basic network topologies have been considered, see Fig. 1.

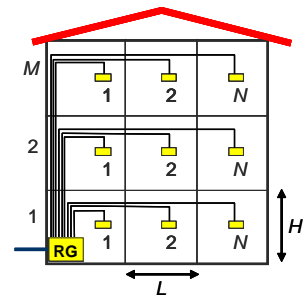

a) point-to-point (P2P)

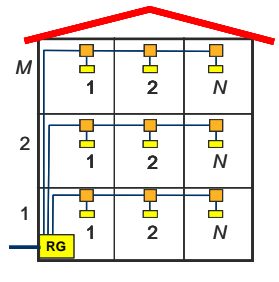

b) bus

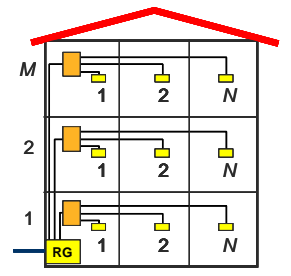

c) tree

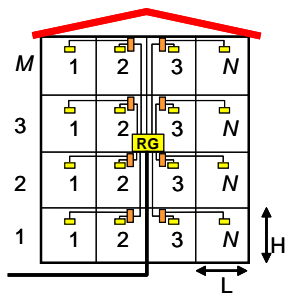

d) star-tree

Fig. 1: In-building network topologies

In the point-to-point (P2P) topology (Fig. 1a), individual cables run from the residential gateway $(\mathrm{RG})$ to each room. This topology allows easy upgrading and maintenance per room, but requires a high amount of cabling with associated installation efforts and duct congestion issues, in particular in larger buildings. The bus and tree topologies are point-to-multipoint topologies, in which cables are shared among rooms and the number of cables to the RG is reduced. Multiple access control techniques are required to give each room a fair part of the shared cable's capacity; nevertheless traffic congestion may occur. With POF and MMF, the splitting nodes typically have to use opticalelectrical-optical signal conversion, which is not transparent for every signal format and hence results in an opaque network. With SMF, all-optical signal splitting can be done in the nodes, allowing future fully signal-format transparent networks. In the following, opaque networks are considered. The bus solution (Fig. 1b) is the most cable-lean, but requires many hub nodes to connect each room. The tree solution (Fig. 1c) has a switch node per floor, from where individual cables run to each room; it needs more cabling than the bus solution, but less active nodes. In larger buildings, the link length restrictions of POF (and Cat-5E) cables may limit the coverage of the building. By putting the RG in a more centralized position, link lengths are reduced in a star-shaped hybrid topology, such as the star-tree one shown in Fig. 1d. 
Three typical building scenarios have been analyzed: a single-family residential home, an office building, and a multi-dwelling building (a.k.a. apartment building). The typical dimensions are listed in Tab. 1.

Table 1: Building scenarios

\begin{tabular}{|l|c|c|c|c|}
\hline & $\begin{array}{c}\text { No. of } \\
\text { floors } M\end{array}$ & $\begin{array}{l}\text { No. of rooms } \\
\text { per floor } N\end{array}$ & $\begin{array}{l}\text { Distance } \\
\text { between floors } \\
H \text { (in m) }\end{array}$ & $\begin{array}{l}\text { Duct length } \\
\text { between wall } \\
\text { outlets } L \text { (in } \mathrm{m} \text { ) }\end{array}$ \\
\hline Residential home & 3 & 4 & 3.3 & 8 \\
\hline Office building & 10 & 50 & 3.8 & 10 \\
\hline Multi-dwelling bldg. & 10 & 16 & 4.0 & 14 \\
\hline
\end{tabular}

\section{Network cost analysis method}

In order to analyze the costs of the various network topologies, the cost items considered are: cables (including installation in a duct), cable ducts (including installation), connectors (including mounting), media converters (optical transceivers, for opto-electronic signal conversion), and signal routing devices (electrical switches, hubs). The market prices of these items vary widely. Based on extensive market surveys, typical values for the prices and power consumption numbers are listed in Tab. 2.

Table2: Costs of network items and their power consumption

\begin{tabular}{|l|c|c|c|c|}
\hline & Cat-5E & POF & SMF & MMF \\
\hline Installed cable costs & $1.8 € / \mathrm{m}$ & $1.7 € / \mathrm{m}$ & $1.74 € / \mathrm{m}$ & $1.95 € / \mathrm{m}$ \\
\hline Max. link length & $100 \mathrm{~m}$ & $70 \mathrm{~m}$ & $1000 \mathrm{~m}$ & $550 \mathrm{~m}$ \\
\hline $\begin{array}{l}\text { Mounted connector } \\
\text { costs }\end{array}$ & $13 €$ & $3 €$ & $15 €$ & $14 €$ \\
\hline $\begin{array}{l}\text { Media converter } \\
\text { costs; power cons. }\end{array}$ & $\begin{array}{c}\text { negligible; } \\
0.65 \mathrm{~W}\end{array}$ & $30 € ; 0,85 \mathrm{~W}$ & $70 € ; 1.15 \mathrm{~W}$ & $40 € ; 1.15 \mathrm{~W}$ \\
\hline $\begin{array}{l}\text { Hub/tap costs; } \\
\text { power consumption }\end{array}$ & $20 € ; 0.2 \mathrm{~W}$ & $20 € ; 0.2 \mathrm{~W}$ & $20 € ; 0.2 \mathrm{~W}$ & $20 € ; 0.2 \mathrm{~W}$ \\
\hline $\begin{array}{l}\text { Switch costs, power } \\
\text { consumption }\end{array}$ & $\begin{array}{c}10 € / \text { port; } \\
0.3 \mathrm{~W} / \text { port }\end{array}$ & $\begin{array}{c}10 € / \text { port; } \\
0.3 \mathrm{~W} / \text { port }\end{array}$ & $\begin{array}{c}10 € / \text { port; } \\
0.3 \mathrm{~W} / \text { port }\end{array}$ & $\begin{array}{c}10 € / \text { port; } \\
0.3 \mathrm{~W} / \text { port }\end{array}$ \\
\hline
\end{tabular}

A duct can host multiple cables in parallel. Its costs $c(N)$ per unit installed length will depend on the installation method (mounted on the wall, or buried into the wall), and the duct diameter. The latter depends on the number of cables $N$ and the cable diameter. From a market survey of circular duct pipes, 
empirical expressions for $c(N)$ have been determined for the various cable types, as listed in Tab. 3.

Table 3: Installed duct costs per meter $c(N)$ for a circular duct hosting $N$ cables

\begin{tabular}{|c|c|c|c|c|}
\hline Cable type & \multicolumn{2}{|c|}{ On-the-wall mounted ducts } & \multicolumn{2}{|l|}{ Buried ducts } \\
\hline $\begin{array}{l}\text { Cat-5E } \\
\varnothing 5 \mathrm{~mm}\end{array}$ & $\begin{array}{l}3.631 € / \mathrm{m} \\
1.938 \mathrm{~N}^{0.356} € / \mathrm{m}\end{array}$ & $\begin{array}{l}\text { for } \mathrm{N} \leq 7 \\
\text { for } \mathrm{N}>7\end{array}$ & $\begin{array}{l}4.631 € / m \\
2.394 \mathrm{~N}^{0.622} € / \mathrm{m}\end{array}$ & $\begin{array}{l}\text { for } N \leq 3 \\
\text { for } N>3\end{array}$ \\
\hline $\begin{array}{l}\text { MMF, SMF } \\
\varnothing 2.5 \mathrm{~mm}\end{array}$ & $\begin{array}{l}3.631 € / \mathrm{m} \\
3.22+0.0301 \mathrm{~N} € / \mathrm{m}\end{array}$ & $\begin{array}{l}\text { for } N \leq 16 \\
\text { for } N>16\end{array}$ & $\begin{array}{l}4.631 € / \mathrm{m} \\
3.66+0.164 \mathrm{~N} € / \mathrm{m}\end{array}$ & $\begin{array}{l}\text { for } N \leq 4 \\
\text { for } N>4\end{array}$ \\
\hline $\begin{array}{l}\text { Simplex POF } \\
\varnothing 2 \mathrm{~mm}\end{array}$ & $\begin{array}{l}3.631 € / \mathrm{m} \\
3.22+0.0301 \mathrm{~N} € / \mathrm{m}\end{array}$ & $\begin{array}{l}\text { for } N \leq 18 \\
\text { for } N>16\end{array}$ & $\begin{array}{l}4.631 € / \mathrm{m} \\
3.56+0.106 \mathrm{~N} € / \mathrm{m}\end{array}$ & $\begin{array}{l}\text { for } N \leq 10 \\
\text { for } N>10\end{array}$ \\
\hline
\end{tabular}

Table 4: Amount of network items needed and total power consumption for different network topologies, as a function of the building dimensions

\begin{tabular}{|l|l|}
\hline Point-to-point \\
\hline $\begin{array}{l}F=\frac{1}{2} N H M(M-1)+\frac{1}{2} M L N(N-1) \\
D=M \cdot H \cdot c(M \cdot N)+M \cdot(N-1) \cdot L \cdot c(N)\end{array}$ & $\begin{array}{l}M C=2 \cdot M \cdot N \\
C=2 \cdot M \cdot N \\
P_{t o t}=P_{M C} \cdot M C=P_{M C} \cdot 2 M \cdot N\end{array}$ \\
\hline Bus & $M C=2 \cdot M+2 \cdot M \cdot(N-1)=2 \cdot M \cdot N$ \\
\hline$F=M \cdot(N-1) \cdot L+\frac{1}{2} H \cdot M \cdot(M-1)$ & $C=2 M+2 M \cdot(N-1)+M \cdot N=3 \cdot M \cdot N$ \\
$D=M \cdot H \cdot c(M)+M \cdot(N-1) \cdot L \cdot c(1)$ & $P_{t o t}=P_{M C} \cdot 2 M \cdot N+P_{s w} \cdot 3 M \cdot N$ \\
$T=M \cdot N$ & \\
\hline Tree & $C=2 M+2 M \cdot N$ \\
\hline$F=\frac{1}{2} M \cdot L \cdot N \cdot(N-1)+\frac{1}{2} H \cdot M \cdot(M-1)$ & $M C=2 M+2 M \cdot N=2 M \cdot(N+1)$ \\
$D=M \cdot H \cdot c(M)+M \cdot(N-1) \cdot L \cdot c(N)$ & $P_{t o t}=P_{M C} \cdot 2 M \cdot(N+1)+P_{s w} \cdot M \cdot(N+1)$ \\
$T=M$ &
\end{tabular}

The amount of network items depends on the building dimensions, i.e. the number of floors $M$, the number of rooms per floor $N$, the distance between floors $H$, and the duct length between wall outlets $L$ (see Fig.); note that the duct usually will not follow the shortest path, so $L$ typically will exceed the room width. The total cable length $F$, the total installed duct costs $D$, the total number of connectors $C$, the number of in-line devices (switches, hubs) $T$, the number of media converters $M C$, and the total power consumption $P_{t o t}$ can be expressed as functions of the building dimensions; see Tab. 4. 


\section{Network cost analysis results}

Using the analysis tools above, the network installation costs (CapEx) per room for a P2P topology are found to increase monotonically with the number of rooms, due to the increasing average cable lengths and duct sizes. For P2MP topologies, the CapEx per room initially decreases as the sharing factor of the common network parts increases, but for larger room numbers it increases again as the average cable and duct length start to dominate [1]. Hence for a small building (residential home) a P2P architecture is attractive, also given its simplicity and easy upgradability. Figure 2.a shows the CapEx breakdown per room for a typical residential home $(M=3, N=4)$ with a P2P topology, using buried ducts (the costs are marginally lower for on-the-wall mounted ducts). For the fiber solutions, duct costs are saved by putting the fibers in the existing ducts of the electricity power wiring (duct sharing); this is not allowed for Cat-5E solutions for safety reasons.

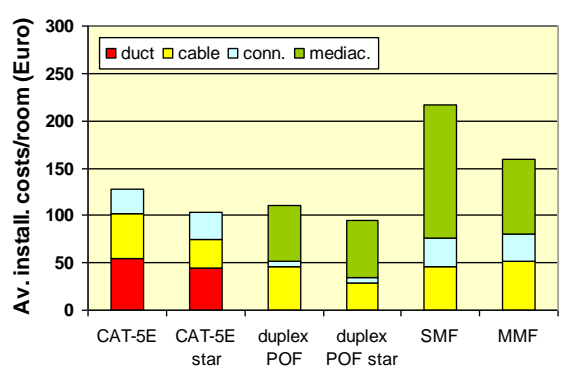

a) Residential home, P2P

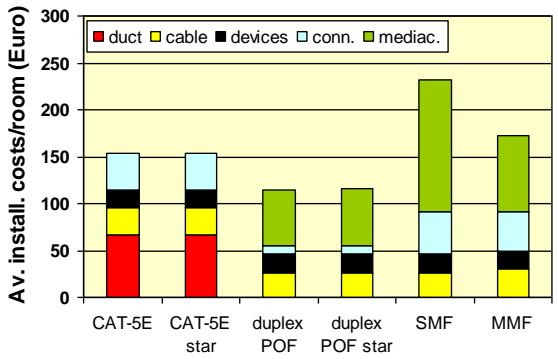

b) MDU building, bus

Fig. 2: Breakdown of CapEx per room with duct sharing for the fiber solutions

For larger buildings (office building, MDU building), the cables and the ducts become the major cost items. Hence a bus topology, which maximizes the sharing of cables and ducts, yields the lowest CapEx per room. Figure 2.b shows the CapEx breakdown for a typical MDU building $(M=10, N=16)$.

As shown in Fig. 2, by means of sharing the ducts of the electricity wiring, the duplex POF solution is a strong competitor regarding CapEx of the established Cat-5E solution; in the near future POF can be expected to outperform Cat-5E, when POF technologies mature, POF market volumes increase, and prices of the media converters decrease. 
A major contributor to the operational costs $(\mathrm{OpEx})$ is the electrical power consumption of the active network elements, which are always-on. Figure 3 shows the power consumption per room for a residential home and for an MDU building. A P2P topology has the least active elements, and hence the lowest OpEx. A bus topology has more active elements; a tree topology has less active elements than a bus one, and thus somewhat lower power consumption, but that OpEx advantage may be offset by the higher CapEx.

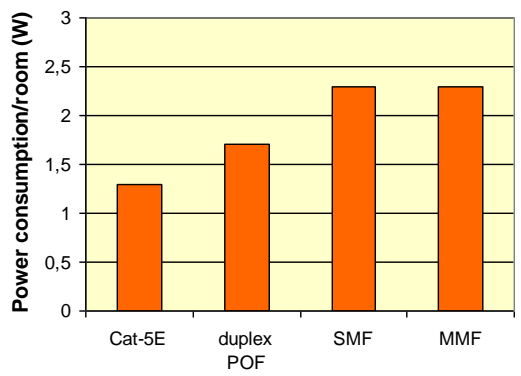

a) Residential home, P2P

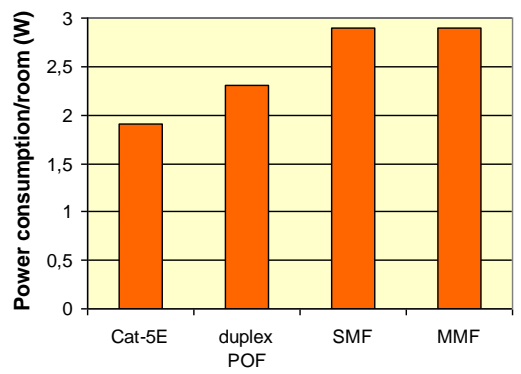

b) MDU building, bus

Fig. 3: Electrical power consumption per room

\section{Concluding remarks}

Large-core POF, in particular when sharing the duct with electricity wiring, is attractive for creating service-integrated in-building networks, from both technical and economical perspective. The cost advantages will increase further when the POF market gets more mature. For smaller buildings (residential homes), a P2P network topology is preferred, and for larger buildings (offices, multi-dwelling buildings, etc.) an opaque bus topology. Partial funding by the European Union in the FP7 projects ALPHA, POFPLUS and BONE is gratefully acknowledged.

\section{References}

[1] A.M.J. Koonen, H.P.A. van den Boom, E. Tangdiongga, H.-D. Jung, P. Guignard, "Designing in-building optical fiber networks", Proc. OFC/NFOEC 2010, San Diego, Mar. 21-25, 2010, paper JThA46

[2] A.M.J. Koonen, H.P.A. van den Boom, H. Yang, C. Okonkwo, Y. Shi, S.T. Abraha, E. Ortego Martinez, E. Tangdiongga, "Converged in-building networks using POF - economics and advanced techniques", Proc. POF 2010, Yokohama, Oct. 19-21, 2010 